\title{
Understanding the Trade Adjustment Assistance (TAA) for Farmers Program ${ }^{1}$
}

Edward A. Evans ${ }^{2}$

\section{Introduction}

International trade liberalization and general globalization of the world economy have meant that growers, businesses, and community groups are constantly being presented with new opportunities and challenges. This in turn requires more frequent adjustment on the part of the players. The adjustment process, however, can be complex and sometimes very painful. Although a country as a whole may benefit from a move towards freer trade, not all individuals and industries in that country will end up being winners. Some will be made worse off and will require assistance to either restructure their current operation to take advantage of the opportunities that become available or transition to new and financially more viable alternatives. This publication discusses the Trade Adjustment Assistance (TAA) for Farmers program, intended to help producers of primary agricultural commodities adjust to increased foreign import competition.

\section{What Is the Trade Adjustment Assistance (TAA) for Farmers?}

The TAA is a special program administered by the United States Department of Agriculture, Foreign Agricultural Service, to assist eligible farmers to cope with increased import competition resulting from trade liberalization. The program provides the following benefits:

- free technical assistance from the Cooperative Extension Service to help explore alternative commodities, marketing opportunities, and alternative enterprises.

- cash payment of up to a maximum of $\$ 10,000$.

- full coverage of tuition for up to 104 weeks of full-time classroom education intended to help agricultural producers transition to different careers.

\section{TAA Background}

Traditionally, trade adjustment assistance in the form of technical assistance and labor retraining services was only provided to non-agricultural businesses and employees. However, The Trade Act

1. This is EDIS document FE498, a publication of the Department of Food and Resource Economics, Florida Cooperative Extension Service, Institute of Food and Agricultural Sciences, University of Florida, Gainesville, FL. Published January 2005. Please visit the EDIS website at http://edis.ifas.ufl.edu.

2. Edward A. Evans, Assistant Professor, Department of Food and Resource Economics, Tropical Research and Education Center, Homestead, FL, Florida Cooperative Extension Service, Institute of Food and Agricultural Sciences, University of Florida, Gainesville, FL.

The Institute of Food and Agricultural Sciences is an equal opportunity/affirmative action employer authorized to provide research, educational information and other services only to individuals and institutions that function without regard to race, color, sex, age, handicap, or national origin. For information on obtaining other extension publications, contact your county Cooperative Extension Service office. Florida Cooperative Extension Service/Institute of Food and Agricultural Sciences/University of Florida/Christine Taylor Waddill, Dean. 
of 2002 amended the Trade Act of 1974 to expand the benefits to producers of raw agricultural commodities when the Administrator of the Foreign Agricultural Service (FAS) determines that increased imports contributed significantly to a specific price decline over the five preceding marketing years. The statute authorizes an appropriation of $\$ 90$ million less administrative expenses for each fiscal year from 2003 through 2007 to provide both technical assistance and cash benefits to eligible producers (USDA/FAS, 2003).

\section{Steps for Accessing TAA Benefits}

In order to benefit from the program, participants must strictly adhere to the TAA procedures and their deadlines (there are 5 steps).

\section{Step 1: Filing the Petition}

The first step in the process is the filing of a petition by a group ( 3 or more) of agricultural commodity producers or their authorized representative for trade adjustment assistance. The petition must state clearly if it is being filed on behalf of all producers in the United States or if they are filing on behalf of producers in a specifically identified impacted area. This is important since only producers covered by the petition will be eligible to apply for the benefits.

The basis of the petition must be injury suffered arising from a shortfall in net income that was caused by a price decline due to import competition of a like or similar product. Petitions are to be sent to the Foreign Agricultural Service (FAS). The petition form is available online at http://www.fas.usda.gov/itp/taa/FAS0930.pdf, or may be requested by phone at (202) 720-2916 or by email at trade.adjustment@fas.usda.gov. Petitions can only be submitted during the period August 15 through January 31 of each applicable fiscal year (October to September). After receipt of the completed petition, the FAS Administrator will publish notification in the Federal Register. This date is regarded as the official filing date.

\section{Step 2: Certifying the Commodity}

Before individual producers can apply for benefits, the commodity must first be certified as being eligible. This process involves the FAS determining whether the petition meets the following criteria:

- The average price of the commodity in the most recent 12 months fell by more than $20 \%$ of the average price over the preceding 5 years.

- Imports of directly competing products increased during the most recent 12-month period.

- Such imports contributed importantly to the fall in domestic price of the commodity.

Results of the FAS determination will be published in the Federal Register as soon as practicable but no later than 40 calendar days after the official filing date of the petition (Step 1).

Commodities meeting the above conditions are said to be certified as eligible for TAA.

\section{Step 3: Applying for Benefits}

Once the commodity has been certified (Step 2), eligible producers have up to 90 days to apply for TAA benefits by submitting Form FSA-229, which is available online at http://forms.sc.egov.usda.gov/eforms/Forms/ FSA0229_030923V01.pdf, or may be obtained at local Farm Service Agency (FSA) offices.

Although the Foreign Agricultural Service (FAS) is responsible for the overall administration of the TAA Program, the Farm Service Agency (FSA) is tasked with implementing the TAA Program at the local level. Among other things, the FSA is responsible for

- informing eligible producers about the program's benefits, eligibility requirements, and required training.

- assisting producers with completing various forms. 
- making sure technical assistance is provided.

- issuing payments.

Information on FSA office locations is available online at http://oip.usda.gov/scripts/ndisapi.dll/oip_agency/ index? state=us\&agency $=$ fsa.

\section{Step 4: Certifying Technical Assistance}

All producers covered by a certified petition (Step 1) and who have applied for TAA (Step 2-submitted FSA-229) are entitled to receive free information and technical assistance from the Cooperative Extension Service. However, before TAA payments can be made, applicants must meet at least once with Extension officers to receive technical assistance (hands-on training). At the end of such meeting(s), participants will be awarded certificates to be used as proof that technical assistance was received. Only producers who have undergone the training and received certificates will be eligible for cash payments.

\section{Step 5: Obtaining Cash Payments}

In order to obtain cash payments under the program, producers have until September 30th of the year in which the petition was approved to submit the following documentations:

- certification showing that they have received technical assistance (Step 4).

- evidence showing that net farm income as reported on IRS Schedule F (Form 1040) and Form 4835 was less than that for the previous year.

- proof that average gross income (AGI) did not exceed $\$ 2.5$ million for the each of preceding three years.

- acceptable production documents for the commodity, such as copies of sales receipts, ledgers, income statement, invoices for custom harvesting.

Each eligible producer may receive up to a maximum TAA payment of $\$ 10,000$ for any given year. Payments are calculated on the basis of the following formula:

Payment Amount $=\mathrm{C} \times 0.5 \times\left[\left(0.8 \times \mathrm{P}_{\mathrm{A}}\right)-\mathrm{P}_{\mathrm{R}}\right]$

- $C=$ amount of agricultural commodity sold in most recent marketing year.

- $P_{A}=$ average national price of agricultural commodity covered by petition for 5 marketing years preceding most recent marketing year.

- $P_{R}=$ average national price of agricultural commodity for most recent marketing year.

For example, assume that a producer of commodity $A$ had a net income in 2003 that was less than the net income in 2002. If commodity $A$ is represented by a TAA petition approved by FAS, then such a producer could apply for TAA. Also, assume that FAS certifies this commodity and that the producer undergoes the necessary training and provides the required supporting documents. The producer is would then be entitled to cash payments. Further, assume that in 2003 the producer sold 3,000 pounds of commodity $A$ at a price of $\$ 1.00$ per pound and that the preceding five-year (1998-2002) national average price for the commodity was $\$ 3.00$. This producer would receive cash payments of $\$ 2,100$ (i.e., 3000 x .5x[(.8x3) - 1]).

\section{Concluding Remarks}

The TAA program for farmers is still evolving. The major advantage of the program is the short-term assistance provided to primary commodity producers to help them cope with some of the hardships created by foreign import competition. A major drawback to the program, however, is the stringency of the eligibility requirement to receive cash payments. By basing eligibility on comparison of current and previous years' total net incomes, many producers are excluded who have experienced a considerable decline in income from a given enterprise but whose overall net income exceeds that of the previous year. Also, it is possible for a producer who recorded negative incomes in two consecutive years to be excluded from benefiting from the program. This could arise in a situation where, for example, the income in the current year is negative $(-\$ 1,000)$ but 
slightly better than the previous year's income $(-\$ 1,500)$. This producer would not qualify for the cash benefit after having suffered hardship in two consecutive years. This is in contrast to a producer whose income in the current year was $\$ 10,000$ and $\$ 15,000$ in the previous year. In this case, the producer would be eligible for cash payments under the program, assuming other conditions were met. Perhaps an amendment to the rule should be to automatically qualify producers with negative income. In addition, because payment is made on only half of the producer's marketed output and only to those producers participating in the current and previous years, producers could find themselves in a situation where they are forced to market their produce to be eligible to participate in the program, even though they know it would be unprofitable. It is not hard to envision a situation where it would be better overall to not incur additional harvesting costs, but that would make the producer ineligible to receive TAA benefits. The program could be modified to base eligibility on whether a commodity was planted or was not harvested instead of limiting payments to the amount of output sold. Finally, although it is recognized that the cash payment is not a subsidy and that the emphasis is on technical assistance, it is a fact that producers who might be in difficult financial situations are less likely to respond positively to technical assistance. Moreover, the formula used to calculate the payments makes it extremely difficult for producers who really need the cash to obtain worthwhile payments. The formula contains at least three safeguard mechanisms to limit payments: (1) the amount payable in a given year is capped at $\$ 10,000$, (2) payments are only made on half of the marketed output, and (3) the effective price used in the calculation is the difference between the five-year average price and the current market price. Hopefully, as the program matures some of the glitches in the system will be addressed.

\section{Contact Information}

Kenneth W. Stokes

Southern Region Risk Management Education Center (SRRMEC)
Texas A\&M Research and Extension Center

1299 North US Highway 281

Stephenville, TX 76401-9635

Phone: 254 968-4144

Fax: 254 965-3759

Email: k-stokes@tamu.edu

William P. Hawke, Project Coordinator

Contract and Grants, The Agriculture Program

Texas A\&M University

College Station, TX 77843

Phone: 979 458-4682

Email: WPHawke@ag.tamu.edu

Edward A. Evans

Tropical Research and Education Center

18905 SW 280th Street

Homestead, FL 33031

Phone: 305 246-7000 x 272

Email: EAEvans@ifas.ufl.edu

\section{USDA Agencies}

- USDA Cooperative State Research, Education, and Extension Service

Technical Assistance for Farmers and

Fishermen at http://www.agrisk.umn.edu/taa

- USDA Foreign Agricultural Service

Trade Adjustment Assistance (TAA) for

Farmers at

http://www.fas.usda.gov/itp/taa/taaindex.htm 
FAS Federal Register Notices at

http://www.fas.usda.gov/info/fr/notices.html

- USDA Farm Service Agency

Trade Adjustment Assistance (TAA) for

Farmers at

http://www.fsa.usda.gov/dafp/psd/TAA.htm

Price Support Notices at

http://www.fsa.usda.gov/dam/forms/

psdnotices.asp

\section{References}

USDA/FAS, 7 CFR, Part 1580, RIN

0551-AA66. 2003. Trade Adjustment Assistance for

Farmers. Federal Register (Rules and Regulations)

68(161):50048-53 (Wednesday, August 20). 